\title{
A comparative conversation analytic study of formulations in psychoanalysis and cognitive psychotherapy
}

\section{Weiste, Elina}

2013

Weiste , E \& Peräkylä , A 2013 , ' A comparative conversation analytic study of formulations in psychoanalysis and cognitive psychotherapy ', Research on Language and Social pÿlnteraction , vol. 46 , no. 4 , pp. 299321 . https://doi.org/10.1080/08351813.2013.839093

http://hdl.handle.net/10138/156623

https://doi.org/10.1080/08351813.2013.839093

acceptedVersion

Downloaded from Helda, University of Helsinki institutional repository.

This is an electronic reprint of the original article.

This reprint may differ from the original in pagination and typographic detail.

Please cite the original version. 
This article was downloaded by: [University of Helsinki]

On: 11 J une 2014, At: 00:39

Publisher: Routledge

Informa Ltd Registered in England and Wales Registered Number: 1072954 Registered office: Mortimer House, 37-41 Mortimer Street, London W1T 3J H, UK

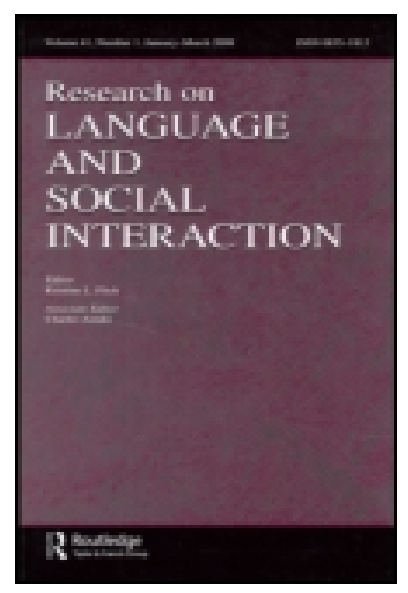

\title{
Research on Language and Social Interaction
}

Publication details, including instructions for authors and subscription information:

http:// www. tandfonline.com/loi/ hrls20

\section{A Comparative Conversation Analytic Study of Formulations in Psychoanalysis and Cognitive Psychotherapy}

\author{
Elina Weiste ${ }^{a} \&$ Anssi Peräkylä ${ }^{a}$ \\ ${ }^{a}$ Finnish Centre of Excellence in Research on Intersubjectivity in \\ Interaction, University of Helsinki , Finland \\ Published online: 25 Oct 2013.
}

To cite this article: Elina Weiste \& Anssi Peräkylä (2013) A Comparative Conversation Analytic Study of Formulations in Psychoanalysis and Cognitive Psychotherapy, Research on Language and Social Interaction, 46:4, 299-321, DOI: 10.1080/08351813.2013.839093

To link to this article: http:// dx. doi.org/ 10.1080/08351813.2013.839093

\section{PLEASE SCROLL DOWN FOR ARTICLE}

Taylor \& Francis makes every effort to ensure the accuracy of all the information (the "Content") contained in the publications on our platform. However, Taylor \& Francis, our agents, and our licensors make no representations or warranties whatsoever as to the accuracy, completeness, or suitability for any purpose of the Content. Any opinions and views expressed in this publication are the opinions and views of the authors, and are not the views of or endorsed by Taylor \& Francis. The accuracy of the Content should not be relied upon and should be independently verified with primary sources of information. Taylor and Francis shall not be liable for any losses, actions, claims, proceedings, demands, costs, expenses, damages, and other liabilities whatsoever or howsoever caused arising directly or indirectly in connection with, in relation to or arising out of the use of the Content.

This article may be used for research, teaching, and private study purposes. Any substantial or systematic reproduction, redistribution, reselling, loan, sub-licensing, systematic supply, or distribution in any form to anyone is expressly forbidden. Terms \& Conditions of access and use can be found at http://www.tandfonline.com/page/termsand-conditions 


\title{
A Comparative Conversation Analytic Study of Formulations in Psychoanalysis and Cognitive Psychotherapy
}

\author{
Elina Weiste and Anssi Peräkylä \\ Finnish Centre of Excellence in Research on Intersubjectivity in Interaction \\ University of Helsinki, Finland
}

\begin{abstract}
The uses of formulation in cognitive psychotherapy and psychoanalysis were compared, by means of conversation analysis, using 53 audio-recorded sessions as data. Two formulation types were found in both approaches: highlighting formulations, which recycle the client's descriptions and recognize therapeutically dense material, and rephrasing formulations, which offer the therapist's version of the client's description and focus on subjective experiences. These formulations may be interactional bearers of common factors in psychotherapy. Two other formulation types were exclusive to one or another approach. Relocating formulations, found only in psychoanalysis, propose that the experiences in the client's narratives are connected to experiences at other times or places. Exaggerating formulations, found only in cognitive psychotherapy, exaggerate the client's talk by recasting it as something that is apparently implausible. The contrast between relocating and exaggerating formulations suggests that, despite recent theories in the two approaches being more compatible, interactional differences still exist between cognitive psychotherapy and psychoanalysis.
\end{abstract}

In the past 10 years, conversation analysis (CA) has made a specific contribution to the understanding of psychotherapy interaction by describing its sequential organization: how the therapist and the client construct their turns in relation to the other's turns (Peräkylä, 2012; Peräkylä, Antaki, Vehviläinen, \& Leudar, 2008). However, the differences and similarities between different therapeutic approaches have not been investigated (for a recent exception, see Kondratyuk \& Peräkylä, 2011). This is highly relevant because the field of psychotherapy consists of numerous approaches, both in terms of clinical theories (e.g., psychodynamic, cognitive, solution-oriented) and in terms of who the participants are (e.g., individual, group, family). Consequently, there is likely to be considerable variation in interactional practices (Peräkylä, 2012). Thus, due to the lack of comparative CA research into different therapeutic approaches, it is unclear if the

Many thanks to Elizabeth Couper-Kuhlen for listening to the data and commenting on an early version of this article. Thanks also to Melisa Stevanovic, Mikko Kahri, Liisa Voutilainen, Mika Simonen, Timo Kaukoma, Pentti Henttonen, and Sanni Tiitinen for their comments on an earlier version of the manuscript; to Maari Kivioja and other transcribers of the data; and to participants of the sociology data sessions at University of Helsinki during 2011-2012.

Correspondence should be sent to Elina Weiste, Finnish Centre of Excellence in Research on Intersubjectivity in Interaction, University of Helsinki, P.O. Box 4 (Vuorikatu 3A), Helsinki, FI-00014, Finland. E-mail: elina.weiste@ helsinki.fi 
findings of previous studies are restricted to the therapy approaches they investigate (Vehviläinen, Peräkylä, Antaki, \& Leudar, 2008, p. 197). Nevertheless, outside the field of conversations analysis, there is a long-standing tradition of comparing different therapy approaches. Earlier studies have shown overall differences between psychotherapeutic approaches in terms of the frequency of different verbal activities (e.g., Elliot et al., 1987; Stiles, Shapiro, \& Firth-Conzens, 1988) and general process characteristics (e.g., Watzke, Rueddel, Koch, Rudolph, \& Schultz, 2008). In the present study, the focus is different: We take up one specific interactional practiceformulations-and use CA to investigate the uses of this practice in two different types of psychotherapy. Thereby, we offer the first CA-based comparative analysis between the two main psychotherapeutic approaches, psychoanalysis and cognitive psychotherapy.

The focus of our comparative study is on formulations, i.e., utterances that show understanding of the previous speaker's turn by proposing a version of it (Heritage \& Watson, 1979). Formulations are good cases for comparison because they have been one of the central topics of earlier CA studies on psychotherapy (for an overview, see Antaki, 2008). CA studies have shown that therapists use formulations for multiple interactional purposes. For example, they can transform the client's talk into psychological issues suitable for closer psychotherapeutic work (Antaki, 2008). Formulations can also be used to manage the agenda of the therapy session and prepare the client's talk for the subsequent actions of the therapist (Antaki, 2008). Our aim in this study is to investigate the differences and similarities in the use of formulations between cognitive psychotherapy and psychoanalysis.

Conversation analytical studies of institutional interaction are perceived as essentially comparative. Typically, the practices of institutional talk are compared with similar practices in ordinary talk or talk between different institutions (Haakana, Laakso, \& Lindström, 2009, p. 21). Comparison can show how institution-specific or generic are the practices that have initially been found in one particular setting (Drew, 2003). Drew (2003) has shown that while formulating is a generic practice in talk-in-interaction, participants in different interactional settings manage different tasks through formulating. For example, Drew found that in news interviews, the interviewer used formulations to make the interviewee's prior speech more newsworthy. In radio call-in programs, formulations were used in part of the argumentation sequences to challenge the caller's position and show the absurdity of the caller's opinion (p. 301, 305). In this study, we will continue the tradition of comparative research on formulations, but instead of examining grossly different institutional settings, we will focus on the differences between two approaches - cognitive and psychoanalytic — within one institutional activity, psychotherapy.

While it is reasonable to assume that the clinical theories of practitioners inform their interactions with clients (Peräkylä \& Vehviläinen, 2003; Peräkylä, Ruusuvuori, \& Vehviläinen, 2005), we do not know much about actual differences in interactional practices. Psychoanalysis and cognitive therapy are good cases for comparison because (a) they are widespread practices, and (b) they are based on explicit and well-articulated clinical theories that are markedly different if not contrastive. In its classical form, psychoanalysis aims at making clients increasingly aware of the psychic events, forces, and emotions that have been hidden in their unconscious mind at some point (usually in early childhood) in their individual development (e.g., Greenson, 1967, p. 26). In contrast to psychoanalysis, the traditional conception of cognitive psychotherapy is more focused on here-and-now problems and does not make reference to unconscious mental processes (Beck, Rush, Shaw, \& Emery, 1979, p. 7). Its core aim is to identify, challenge, and correct clients' distorted conceptualizations and dysfunctional beliefs in order to relieve their symptoms 
and achieve positive changes in their emotional experiences (Beck et al., 1979, p. 6-7). While the "classical" theoretical positions of psychoanalysis and cognitive therapy are thus contrastive, more recent theories in both approaches are less so (see, e.g., Fonagy, Gergely, Jurist, \& Target, 2002; Greenberg, 1997; Guidano, 1991; Safran, 1998; Sandler, 1994): Cognitions have become an issue in psychoanalysis, as have unrecognized emotional conflicts in cognitive therapy.

Yet another line of clinical theorizing relevant to our research task comes from a more general psychotherapeutic theory that is not committed to either of the specific approaches that we compare. The increasingly popular common factors theory (e.g., Wampold, 2001) proposes that different psychotherapeutic approaches have common components related to the working alliance between the client and the therapist. It is suggested that these common factors are more important for the therapy outcome than approach-specific components, such as specific therapy techniques (e.g., Horvath, 2001; Lambert \& Barley, 2001; Wampold, 2001). In sum, a comparison of interactional practices in psychoanalysis and cognitive psychotherapy is needed because (a) in their classical form, the respective clinical theories are contrastive; (b) more recent theories in both approaches are more compatible; and (c) a new clinical theory that is more generic claims that the really important factors in therapy are actually common for all approaches. We take formulations as a window through which to view what is different and similar between the two approaches.

\section{DATA AND METHOD}

The data for this study consist of 30 audio-recorded sessions of psychoanalysis and 23 sessions of cognitive psychotherapy. As one psychoanalytic session lasts 45 minutes and a cognitive psychotherapy session 60 minutes, the data examined for this article involve approximately 23 hours of interaction from both approaches. The data come from four different dyads: one therapist and two clients from both approaches. The therapists are well-trained, experienced private practitioners. The cognitive therapist (female, in her fifties) is a a longstanding member of the Finnish Association for Cognitive and Behavior Therapies. This association includes both behaviorally focused and more constructivist or "post rational" (Guidano, 1991) strands of cognitive therapy, and it is a member of the European Association for Behavioral and Cognitive Therapies (EABCT). The cognitive therapist in our data also has long experience in training cognitive therapists. The psychoanalyst (male, in his sixties) is a longstanding member of the Finnish Psychoanalytic Society. This association includes the classical Freudian as well as neo-Freudian (such as object relations or self-psychological) psychoanalytic schools and is a member of the International Psychoanalytic Association (IPA). Apart from his psychoanalytic practice, the psychoanalyst in our data has served as a trainer of family therapists. It is reasonable to assume that in terms of training and experience, these therapists are representative of their respective therapeutic approaches.

We asked the therapists participating in the study to recruit clients suffering from mood or anxiety disorders who were not psychotic. The therapists also considered the effects that the recording would have on the therapy and recruited clients who would not suffer from the recording of the sessions (for example, by excluding clients with a paranoid personality). Both clients in cognitive therapy were women in their twenties who suffered from depression. In addition, one also suffered from panic attacks. During the therapy process one client's problems were discussed in terms of lack of security and inversion of aggression (from other people to the client 
herself). The other client's therapy process was focused on the critical and rejecting relationship that the client had toward herself and other people. In psychoanalysis, one of the clients was a man in his forties, and the other client was a woman in her sixties. As is typical for psychoanalysis, the discussions did not focus so much on particular symptoms as on the life histories and the current everyday experiences of the clients. Difficult childhood events were investigated in both psychoanalyses: for one client the death of a sibling and for the other separation from her biological parents. The repercussions of these events in the clients' current experience, feelings of insecurity or difficulties in grieving, were repeatedly discussed in the sessions. The data were collected in Finland between 1999 and 2009 by a research group led by the second author at University of Helsinki. The outcome data for the results of the therapy processes are not available for any of these therapies. Informed consent was obtained from the clients and the therapists. All names and other details making possible the identification of the participants have been altered in the text and data excerpts.

In the data analysis, the original recordings were listened to a number of times, and reoccurring interactional patterns, in our case formulation sequences, were identified. After the identification of formulation sequences, all instances were collected from the data at hand. Our collection from a dataset of psychoanalysis ( $22 \mathrm{~h} 50 \mathrm{~min}$ ) and cognitive psychotherapy ( $23 \mathrm{~h}$ ) consisted of 224 formulations. Next, all the instances from the collection were qualitatively analyzed case by case to specify the nature and variation of the phenomenon in question. Four different formulation categories were created on the basis of their primary interactional function, paying attention to their content, lexis, and implications for social action. After the formulations were divided into categories, their distribution across the two forms of therapy was calculated. Thus, the formulations were "qualified for quantitative treatment": Through a detailed qualitative analysis, we made sure that the formulations shared the same features and belonged to the same phenomenon (see Schegloff, 1993, p. 115). Finally, specification of how formulations that have a particular distribution in one form of therapy perform specific work with respect to that approach was discussed.

During the first stages of data analysis, selected segments of the recordings were regularly investigated in group meetings (data sessions) attended by the members of the research group led by the second author. In the data sessions, a consensus on the analysis (identification of formulation sequences and their different types) was sought among the trained CA researchers. This is a standard CA method of quality assurance for data analysis. However, the standard CA methodology does not require analyses of all of the data instances by more than one trained analyst. In this study, the collection of formulation sequences and analysis of the instances of these sequences was carried out by the first author. As is common in CA-based work, double coding was not used. The validity of the analysis is controlled, ultimately, by presenting instances of the data in this research report and by drawing on the interactants' own interpretations (made public in their actions) concerning the meaning of the preceding talk (Peräkylä, 2011b; Sacks, Schegloff, \& Jefferson, 1974).

Our classification of formulations overlaps in several ways with the analyses of psychotherapeutic formulations presented in earlier research (see especially Antaki, Barnes, \& Leudar, 2005; Davis, 1986; Hutchby, 2005; Vehviläinen, 2003), and we refer to relevant earlier studies in the following text. However, in order to convey a clear comparative picture of formulations in two different types of psychotherapy, we have used our own terms to refer to the features and functions of formulations, even in those cases where they appear in earlier research referred to in this 
article. It should also be noted that the main axis of our analysis is the description of experience (see Peräkylä, 2012). We are concerned about the ways in which the therapist's formulation is positioned vis-à-vis the client's description of his/her experience: how it validates, transforms, interprets, or challenges that description. Thus, the other interactional aspects of formulations, for example in the agenda management of the session (Antaki, 2008), are less central to our analysis.

\section{FOUR TYPES OF FORMULATION}

There were four kinds of formulation in our data. In all of them, the therapist dealt with the client's description of his/her experience. Some of the formulations involved (re-)descriptions that were rather close to the client's initial descriptions, while others were, in different ways, further away from the original description. The therapist remained closest to the client's description in formulations where the therapist highlighted some part of the client's account. In contrast, the therapist was somewhat further away from the client's description in formulations where the therapist rephrased a key part of it. Finally, the therapist expanded on the client's description still further in the remaining two types of formulation: formulations that relocated the client's talk by suggesting it had an underlying meaning, and formulations that exaggerated the background assumptions and thoughts that the client's narrative descriptions embodied. In the following we will begin with formulations that remain close to the client's initial descriptions.

\section{Formulations Highlighting Descriptive Elements}

In a highlighting formulation, the therapist selects a part of the client's prior turn, recycling some of its key descriptive elements. Such elements contain therapeutically relevant information, such as emotionally heightened descriptions of the client's experiences. By formulating these key descriptions, the therapist shows that (s)he has listened to and understood the client's description. These formulations may also do important preparatory work for subsequent actions by the therapist (Antaki et al., 2005; Bercelli, Rossano, \& Viaro, 2008). Even though these formulations are contingent on clients' prior turns, they are also the first pair-parts of formulation decision sequences (Heritage \& Watson, 1979). Sequentially, the therapist's formulations make relevant the client's confirming or disconfirming responses. In our corpus, a client most often responds with a minimal confirmation and thereafter continues his/her narration. In the following extract from cognitive psychotherapy, the client talks about her persistent fear of being physically assaulted when out in the city. This fear is particularly intense at night, even when the client is with her boyfriend, Ville. The client's talk is hesitant and perturbed, involving self-repairs and changes in the direction of syntactical construction.

\section{Extract $1 \mathrm{CT}$}

01 C: <yöllä> nii en mä välttämättä? (0.8)

$<\overline{a t}$ the night time $>$ I don't necessarily? (0.8)

02

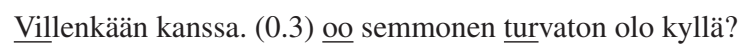

not even with Ville. (0.3) I have that kind of unsafe feeling indeed? 
$03(0.3)>$ emmä jotenki $<$ usko että se niinku pystyis puolustamaan mua?

(0.3) $>$ I don't $<$ think that he could like defend me?

04

(0.9)

$05 \mathrm{~T}:{ }^{\circ} \mathrm{mm}-\mathrm{m}^{\circ}$.

06 C: \#mmm\# (0.4) keltään että,

\#mmm\# (0.4) from anyone that,

07 T: et Villenkin kanssa on turvaton $=\mathrm{m}[\mathrm{m}$.

that even with Ville you feel unsafe $=m[m$.

08

C:

[n- $\uparrow$ nii:.

$[y-\uparrow$ yeah:

09

10

C: $\quad$ KRÖHM et joskus miettii just et

KRÖHM that sometimes I have thought about that

pitää $^{\circ} \mathrm{et}^{\circ}>$ mä haluisin hommata jonku, $<(0.6)$ semmosen laillisen

I have to ${ }^{\circ}$ that ${ }^{\circ}>I$ would like to get some of those, $<(0.6)$ legal

itsepuolustusvälineen.

self-defense tools.((continues))

The therapist's formulation comes in line 7, highlighting the key descriptive element of the client's account. The client's description of being afraid, even when accompanied by her boyfriend, demonstrates a problematic feeling and is thus psychotherapeutically relevant. The formulation is constructed using the same lexical elements used by the client: The therapist recycles the terms (with Ville, be unsafe) from the client's prior talk (Bercelli et al., 2008, p. 46; Peräkylä, 2004). Furthermore, on completion of her formulation (line 7), the therapist produces a $\mathrm{mm}$ particle. $\mathrm{Mm}$ conveys confirmation or agreement, and by producing it at this point, the therapist positions herself as the recipient of her own formulation. Thereby, she orients to her formulation as if it were something that the client could had actually said. In line 8 , the client offers confirmation, after which she continues her narrative (lines 10-12). Later in the same session, the therapist returns to the client's problematic experience. However, at this point, it appears that the therapist is primarily using the formulation to show that she understands and is listening to the client's account, thereby inviting her to continue.

Extract 2 shows a highlighting formulation taken from psychoanalysis. Prior to the extract, the client had been talking about the time in his childhood before his siblings, Simo and Liisa. At that time the client was living with his parents in a place called Anttola. The client intimated that stories about his time in Anttola gave him comfort.

\section{Extract 2 PSA}

$01 \mathrm{C}: \quad>$ ja sit se on niinku $<$.hh jos ajattelee että et siin on ollu hh $>$ and it is like $<$. hh if one thinks that there has been $h h$ 


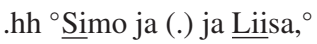

.$h{ }^{\circ} \underline{{ }^{\circ}}$ imo and (.) and Liisa, ${ }^{\circ}$

$04 \quad(5.2)$

05 C: niin se on ollu se Anttola tarina semmonen joka on ollu so the story of Anttola has been the one that has been

06 vain minun ${ }^{\circ}$ tarina ${ }^{\circ} .=$ only $\overline{m y}{ }^{\circ}$ story ${ }^{\circ} .=$

$07=\underline{\text { minä oon ainoostaan ollu }}{ }^{\circ}<$ siellä Anttolassa $>$ äidin kans ${ }^{\circ}$. $=$ only $\underline{I}$ have been ${ }^{\circ}<$ there in Anttola $>$ with mom $^{\circ}$.

$08 \quad(0.4)$

09 T: ${ }^{\circ}$ nii:. ${ }^{\circ}$

${ }^{\circ}$ ye:s. ${ }^{\circ}$

$10 \quad(3.2)$

11 T: ${ }^{\circ}$ et sinä oot ollu sillon ainoana lapsena. ${ }^{\circ}$ ${ }^{\circ}$ that you have been then the only child. ${ }^{\circ}$

12 C: ${ }^{\circ}$ nii::, ${ }^{\circ}$

$13 \quad(2.6)$

14 C: ${ }^{\circ}$ eikä kahta muuta sillon vielä ollu .

${ }^{\circ}$ then the two others were not there yet ${ }^{\circ}$.

In line 9, the therapist responds with the nii-particle. Sorjonen (2001) has shown that the Finnish response particle nii is used in situations where the first speaker has asserted something that is related to his/her sphere of experience. Responding with the nii-particle is a way for the therapist to show recognition of the client's experience, and thus it is a resource for displaying affiliation and understanding. The therapist's formulation (line 11) also shows that he is listening to and understands the client's account. The formulation highlights the key descriptive element, being the only child, of the client's description. It is also psychotherapeutically relevant because it formulates the essential part of the client's description, that of feeling comforted by his memories of Anttola. The core of the therapist's formulation is lexically composed of recycled words: I have been in line 7, you have been in the therapist's turn in line 11, only (Finnish ainoastaan) in line 7, and only (modified to ainoana) in line 11, and children (line 2) and child in the therapist's formulation. In line 12, the client confirms the formulations with the nii-particle and continues his narration. Later in the session, the therapist returns to talk about the time when the client was the only child and the possible effect that the time had on the client's relationship with his parents. However, at the point from which Extract 2 is taken, the therapist only seems to acknowledge the client's experience.

To sum up, the formulations described in this section selected therapeutically dense material from the client's narrative descriptions, to show the therapist's understanding of what the story was about. In their lexical design, these formulations preserved features of the client's talk, and by selecting some part of the client's description and recycling elements from it, the therapist 
undermined some part of the description. What is clear is that these formulations were highlighting something that was already there in the clients' talk. Sequentially, the clients minimally confirmed the formulations before continuing their narrations. However, there were also formulations in our data that altered the clients' narrations, and this is the subject of the following section.

\section{Formulations Rephrasing Descriptive Elements}

Many studies of formulations in psychotherapy suggest that their key task is to transform the client's talk: to reformulate the client's descriptions in terms that render them psychological issues suitable for therapeutic work (Antaki, 2008; Antaki et al., 2005; Davis, 1986; Hak \& De Boer, 1996; Hutchby, 2005). In such formulations, the therapist transforms the client's account and adds some elements that were not originally in the client's turn. In our data, there were three types of formulation that accomplished such a transformation: relocating, exaggerating, and rephrasing. We will first discuss rephrasing formulations.

In rephrasing formulations, the therapist proposes his/her own version of the client's description. Rather than recycling the client's descriptions (as the therapist does in highlighting formulations), the therapist offers his/her reading of a key aspect of the client's narration (cf. Bercelli et al., 2008). ${ }^{1}$ The therapist's formulation focuses on the client's subjective experience (rather than on the other elements available in the client's narrative) and rephrases that experience in generic and somewhat abstract psychological terms. Thereby, the rephrasing formulations invite the client to focus his/her talk more on the subjective meaning of his/her own experience. Because these formulations alter the "point" of the prior version offered by the client, responses indicating confirmation are insufficient (in contrast to highlighting formulations). Rephrasing formulations invite the client to produce responses of extended agreement or disagreement that focus on the client's own experience (see also Bercelli et al., 2008; Peräkylä, 2005). Then, after the client response, the therapist continues to work with the formulated feeling. Extract 3 comes from cognitive psychotherapy. Here, the client is describing her feelings on a morning bus on her way to work.

\section{Extract $3 \mathrm{CT}$}

01 C: ei silloin ei, (.) haluais nähä ketään ihmisiä ja? in those days I don't, (.) want to see anyone and?

$02(3.0)^{\circ} \mathrm{ja}^{\circ}$ (.) jos (.) jollain $\uparrow \underline{\text { bussiin tulo kestää }}$ (3.0) ${ }^{\circ}$ and $^{\circ}$ (.) if (.) someone comes to $\uparrow$ the bus a bit slower

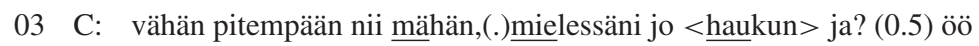
then $\underline{I}$, (.) in my mind I already < criticize them $>$ and? (0.5) erm

$04 \mathrm{~T}: \mathrm{mmm}$.

\footnotetext{
${ }^{1}$ This kind of therapeutic task has many similarities to the actions that Bercelli et al. (2008, p. 48) have identified as reinterpretations. In our data, besides the formulations discussed in this section, there were also reinterpretations exhibiting the characteristics pointed out by Bercelli et al. We do not discuss reinterpretations in this article.
} 
C: $\quad$ kaikkee tommosta ${ }^{\circ} \mathrm{et}^{\circ}$ ?

things like ${ }^{\circ}$ that $^{\circ}$ ?

06 T: eli sit siin on aika voimakas semmone ärsyyntyny

so then there is a quite strong such an irritated

07 [ja agressiivinenki olo. [and even aggressive feeling.

08 C: [joo: no siin hirveen $<\uparrow \underline{\underline{h} e r k a ̈ s s a ̈ ~}>$ ainaki \#just ärsyyntymään [yeah: very $<\uparrow \underline{\text { easily }}>$ one gets at least \#irritated

$09>$ silleen niinku (.) rupee ärsyttää<\# .hhh ${ }^{\circ}$ hirveen herkästi ${ }^{\circ}$. $>$ like that like (.) it begins to irritate $<\# . h h h^{\circ}$ so easily ${ }^{\circ}$.

$10 \quad(2.5)^{\circ}$ että ärtynyt olo?

(2.5) ${ }^{\circ}$ so it is the irritated feeling ?

11 T: M-hm.

$12 \quad(2.7)$

13 T: $\quad$ Mut sä et pidä tota sitte. (1.0) .hh semmosena joka But you don't think that as. (1.0). hh something that

vois olla (.) aika yleistäki. .hehh

could be (.) quite common. .hehh

The therapist's formulation comes in lines 6-7. In response to the client's detailed description of the repetitive events on a morning bus, the therapist renames the core feelings experienced by the client and takes the focus away from the details of the narration and from the external events that triggered the client's experience in the narrative world. Using common psychological vocabulary, the therapist offers an explanation of the client's experience, to which she then directs the client's attention. Irritated and aggressive feelings are not the words used by the client; by offering them, the therapist proposes her own version of the client's description. In her response (from line 8 onwards), the client eagerly agrees with the therapist's formulation, and she indeed focuses on her own subjective experience (rather than the external narrative events), adopting one of the therapist's terms (irritated, see lines 8, 9, and 10; note, however, that she focuses away from the other proposed feeling, aggression). In line 11, the therapist receives the client's response with the acknowledgment token $m-h m$, which is followed by a pause (line 12). While the client does not extend her response, the therapist continues to work with the client's experience. In lines 13-14 she challenges the client's intense experience by stating that the client's feelings are actually something very common. With this turn the therapist invites the client to explore her feelings and experiences from another perspective.

Next we will show an example of a rephrasing formulation from psychoanalysis. The client is talking about his fear of becoming unfairly criticized at work.

Extract 4 PSA

01 C: mut että se niinku se tuntu niinku tosi pahalta niinku tavallaan but that it felt like very bad that kind of 
02 se henki vielä että, .hhhh ikään ku tässä niinku, (1.5) olisi oltu atmosphere that, .hhhh as if I would have been like, (1.5)

03 hirvittäviä riistäjiä ja pahantekijöitä ja hhh huijattu ja hhhmm. terrible oppressor and criminal and hhh cheated and hhhmm.

04

$05 \mathrm{C}$ : se valvotti mä kävin neljän aikaan vielä hiip ${ }^{\circ}$ pailemassa ${ }^{\circ}$. that kept me up I was around four o'clock still up ${ }^{\circ}$ and around $^{\circ}$.

06

07 T: eli sä olit $>$ itseasiassa $<\underline{\text { ahdistunu, }}$ so you were $>$ actually $<\underline{\text { anxious, }}$

08 C: erittäin ahdistunut. very anxious.

10 C: .mthh ja varsinkin vielä ku sitähh läpyskää lukee niin siinä .mth and especially when one reads that paper ((collective labor agreement))

11 niinku selvii kyllä (0.6) yhellä silmäyksellä että se itseasiassa you can see (0.6) with one look that actually

12 se heikentää \#noitten ihmisten työoloja\#. it weakens the \#working conditions of those people\#.

((33 lines of the client's description of the situation in the work place removed))

46 C: .hh et se on minulle jotenki vaikee (.) ollu koko ajan se, .hh that it is somehow difficult for me (.) it has been all the time,

48 C: mhh se työnantajan (1.7) rooli, mhh that role of (1.7) employer,

49 T: .mhh oisko niin et sinä oikeestaan olet loukkaantunut. .mhh could it be that in fact you feel offended.

The client describes a brooding conflict that had occurred in his workplace. In line 5, he reports how thought of this conflict kept him awake throughout the night. In his formulation (line 7), the therapist renames the client's core feeling. As in Extract 3, he also focuses away from the external details of the narration, and using psychological vocabulary, proposes what the client's experience was. The marker itseasiassa ("actually") $)^{2}$ in line 7 reinforces the impression that the therapist's assertion is based on his own reading of the client's talk. In line 8, the client eagerly agrees with the formulation, repeating the word anxious, brought in by the therapist, and adding

\footnotetext{
${ }^{2}$ Clift (2001, p. 286) has found that in English actually occurs in situations where "the actually-speaker's" turn is in potential conflict or contrast with that of another speaker's prior turn. Actually also occurs as a marker of the topic shifts or changes. Here it seems that there might be some similarities with the use of itseasiassa in Finnish. At least in this
} 
the intensifier very. The client continues with a long description of the situation. The description first focuses on "outside" events such as labor contract issues but then returns to the client's own experiences as an employer. In line 49, the therapist continues to work with the client's feelings: The client is not only anxious (line 7) but also feels offended (line 49).

To conclude, rephrasing formulations bring in more abstract psychological vocabulary and offer the therapist's perspective on the matter at hand. These formulations invite clients to shift the focus of their talk more toward the dynamics of their own subjective experiences. In our examples the clients' responses were agreements (or disagreements) extended with personal descriptions, and in their next turn, the therapists continued to work with their clients' experience. In the next section we will introduce a third formulation category, relocating formulations, in which the content of talk is taken even further away from the client's original descriptions.

\section{Relocating Formulations}

Our dataset included formulations that transformed the descriptions in the client's narrative in a radical way. Rather than just rephrasing the client's description, these formulations proposed that the experiences described in the client's narrative were connected to experiences at other times or places. Thereby, the formulations either offered explanations for the experiences just described by the client or treated them as symbolic representations of some other experiences.

As earlier conversation analytical work (Peräkylä, 2005, 2012; Vehviläinen, 2003) has shown, most often this kind of interpretative work is done by the therapist proffering independent firstposition statements that convey his/her own view on matters under discussion. In earlier work, such utterances have been called interpretations. However, in terms of sequential and epistemic organization, interpretations are different from formulations that we are examining in this article. Nevertheless, formulations can also convey interpretative ideas (Vehviläinen, 2003). A formulation can prepare for an interpretation proper by introducing topical elements that invoke unconscious meanings in the client's talk. In such cases, the emerging interpretation can then be built on the material invoked in the formulation. Furthermore, sometimes interpretative ideas are entirely delivered as a formulation. In such cases, the formulation does not prepare for an interpretation to come, but as far as the content of the talk is concerned it is the interpretation. Finally, as Peräkylä (2011a) recently suggested, a formulation can also be a vehicle for a thirdposition action after the therapist's interpretation: When the client has taken up an interpretation and elaborated on it, the therapist can formulate the client's response, thereby bringing in further layers of unconscious meaning.

In concrete instances, it is not always clear whether a relocating formulation prepares for an interpretation proper, conveys the actual interpretation, or involves a third-position action after the client's response to an interpretation. Interpretative talk can involve several cycles of the therapist's interpretative utterances and the client's responses. A third-position formulation can also prepare for a new interpretation, or even convey one, which is the case in Extract 5. In the interaction prior to Extract 5, the therapist had pointed out to the client that his talk was very controlled. The client has then told the therapist about a childhood memory where his father tried

extract, it seems to mark the "therapist directedness" of the formulation by contrasting it with the client's previous turn. It could also be that the formulation introduces a topic shift to direct the client's attention to his emotion. 
to teach him to read; the client felt that his father was not a good teacher. After that, the therapist interpreted the description as meaning that the client was irritated when being taught by his father and also felt the same about his interaction with the therapist. The client also agreed with the therapist's claim, noting that the childhood memory had some similarities to the therapeutic relationship. In the first lines (1-4) the client elaborates on that similarity.

\section{Extract 5 PSA}

01 C: myöski $>$ samalla niinku se että $<$.hh usein niinku siinä,(.)

also $>$ at the same time that it $<$.h h often in that, (.)

$02 \quad$ \#m- m:::\# opetustilanteessa

\#m- m:::\# in that teaching-situation

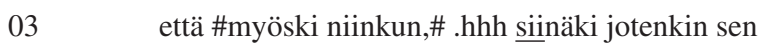

that \#also like,\# .hhh also there somehow

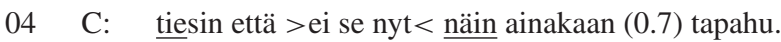

$\bar{I}$ knew that in any case $>$ it doesn't happen $<(0.7)$ like this.

05

(1.0)

06 T: et nyt sinul on sama tunne

that now you have the same feeling

07

et ei se näin ainakaan tapahdu.

that in any case it doesn't happen like this.

08

09

C: ${ }^{\circ}$ nii. ${ }^{\circ}$

${ }^{\circ}$ yes. ${ }^{\circ}$

10

(1.4)

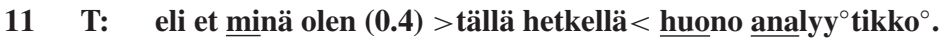
so that I am (0.4) $>$ at the moment $<$ a bad ana $\underline{\text { and }}^{\circ}$ lyst ${ }^{\circ}$.

C: $\quad$.hhh hhmmm

15 T: nyt \#minä\# ajattelen et tähän on aika tärkeä liittää .hh (0.5)

now \#I\# think that it is important to connect this to .hh (0.5)

16 mahdollisesti vielä yks asia, hh oot sinä muistanu et one more thing, .hh have you remembered that

tämä pitäis maksaa.

you should pay this.

((54 lines of the therapist's interpretation removed))

71 C: .mth mut se on niinku se .hhh hhh se tunne mikä siinä

.mth but it is that .hhh hhh that feeling that

72 niinku mulla oli sillon se: se oli aivan epätodellinen.

I had then it: it was totally unreal.((the client continues)) 
The first relocating formulation in lines 6-7 involves the therapist's third-position action following the client's response to the therapist's initial interpretation (not shown). The closing part of the client's response is shown in lines 1-4. On the other hand, the formulation in lines 6-7 also prepares for the further interpretation in line 11. With the formulation in lines 6-7, the therapist shifts the focus of the description from the past (C's father teaching $\mathrm{C}$ ) to the present (the ongoing therapy session), thereby suggesting that the childhood memory and the ongoing therapy session are connected. Orientation to such connectedness is there already in the client's preceding turn (lines 1-4): also there (line 3) implies that what the client is saying (about his father) is also true for other situations. By designing his utterance as a formulation of the client's talk, the therapist implies that the connection already existed in the client's talk. The connectedness of the two spheres of experience is demonstrated by the therapist recycling a key description from the client's utterance (see Peräkylä, 2004) (lines 4 and 7: in any case it doesn't happen like this). In this relocating formulation, the organization of recycling is different from that in highlighting formulations (see Extracts 1 and 2): Here, the description of experience in one context (childhood with father) is transferred to another context (present with the therapist), while in highlighting formulations, the context remains the same.

The second relocating formulation in line 11 takes the interpretation one step further. The client's criticism of his father, discussed shortly before the segment, (where the client characterized his father as not a good teacher) is now invoked by the therapist through his lexical choices, but the target of the criticism has changed: The therapist is a bad analyst. The turn's initial so that (line 11) frames the criticism as something conveyed in the client's prior talk. The client does not respond to the therapist's formulation (long silence in line 12). Although the formulation is carefully grounded in material offered by client's previous talk, it is interactionally difficult to deal with: While the formulation structurally prefers an agreeing response, the point of this relocating formulation is that the client is directly criticizing the therapist. Both agreement and disagreement would be equally problematic. In line 13, the client sighs but still does not provide a response.

After the client's silence, the therapist takes a turn (line 15) in which he expands his formulation by suggesting that the client's forgetfulness in paying for the therapy sessions might also be linked to the issues just addressed. (The therapist seems to suggest that if the client considers him a bad therapist, he might not want to pay him.) By extending the formulation, the therapist treats the activity at hand as still being open, and he also elicits further participation from the client. Eventually after further expansions and rephrasings of the formulation, the client actually starts to elaborate on his thoughts relating to the formulation (see line 71).

To conclude, relocating formulations transform the content of the description that is being formulated. Compared to rephrasing formulations, this form of transformation is more radical: Relocating formulations propose that the experiences described in the client's narrative are connected to experiences at other times or places. Sequentially, these formulations share features with the rephrasing formulations: Both invite agreement/disagreement and elaboration of the client's own experience.

Next we will move on to our fourth formulation type: exaggerating formulations. As with rephrasing and relocating formulations, exaggerating formulations also transform the client's description and add some elements that were not originally in the client's turn. However, the sequential features of exaggerating formulations are quite different from the previous formulations, as they seek disagreement, rather than agreement. 


\section{Exaggerating Formulations}

Exaggerating formulations are constructed to challenge the client's previous talk by recasting it as something that is apparently implausible or even absurd. Sequentially, in exaggerating formulations the therapist redesigns a description given by the client in such a way as to elicit disagreement from the client. In cases where the client nevertheless agrees with such a formulation, the therapist regularly expands the sequence by pursuing a disagreeing response. Where the therapist challenges the client in our data, the formulations can be seen as having two somewhat different tasks: The exaggerating formulation can be a vehicle for delivering the actual challenge (see Extract 6) or, alternatively, the formulation can prepare the ground for a challenge which will then be delivered by means of some other conversational move, such as a question (see Extract 7).

In Extract 6, the client is talking about her problematic relationship with her mother. Earlier on (data not shown) the participants have agreed about the poor parenting that the client has received from her mother. In spite of this, the client explains that she feels need to be humble and obedient (see lines 1-4). The client also says that her mother demands such obedience from her (lines 6-8). In lines 12-13, the therapist formulates the mother's position as reported by the client. In her formulation, the therapist invites the client to disagree with her mother's position, thereby challenging the client's way of thinking.

\section{Extract $6 \mathrm{CT}$}

01 C: mut et jotenki tuntuu et on velkaa ja (1.0) pitää olla but that somehow it feels like being in debt and (1.0) one has to be

02 nöyrä eikä saa nousta sitte sen takii (.) niinku

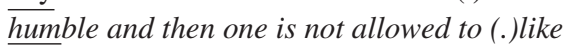

03 (0.7) sitä vastaa mitenkää koska on niin. (0.7) resist her in any way because it's like.

$04 \quad(0.5)$ on saanu siltä, (1.5) $\downarrow$ kaik $^{\circ} \mathrm{ki}^{\circ}$. (0.5) one has received from her, (1.5) $\downarrow_{\text {every }}^{\circ}$ thing ${ }^{\circ}$.

06 C: niinku se aina itekki sanoo et kaikki ootte saanu like she herself always tells us that you have received everything

07 ja (.) että (0.3) että (.) ei pitäs olla mitään valittamista and (.) that (0.3) that (.)you shouldn't have anything to complain

$08 \quad$ \#ja\# (0.3) et (0.6) kiittämättömii ootte. \#and\# (0.3) that (0.6) you are ungrateful.

10 T: $\downarrow$ mm- $\uparrow \mathrm{hm}$

12 T: nii et jos vanhemmat \#antaa lapsillee\# ruokaa \#ja vaatteita\# .hh so that if parents \#give their children\# food \#and clothes\#.hh 
ni lasten pitää koko ajan tuntee suurta kii ${ }^{\circ}$ tollisuutta ${ }^{\circ}$. then the children have to feel immense grati ${ }^{\circ}$ tude all the time ${ }^{\circ}$.

14 $(0.4)$

15 C: nii järki sanoo että £ei: hhh£

yea $\bar{h}$ the reason says that $£$ no: : hhh£

The therapist's formulation in lines $12-13$ is organized as an if-then clause: if parents, then children. The formulation generalizes the position expressed by the client's mother to apply to parents and children in general (not only to the client and her mother), which increases the argumentativeness of the turn. The turn's initial so that (line 12) frames the argument as something conveyed in the client's prior talk. However, the therapist revises the meaning of the "if" and "then" parts. In line 6, the client reports mother saying you have received everything, while in line 12 the therapist refers to something that is self-evident: parents give food and clothes to their children. Likewise, the "then" part is revised from a prohibition to complain (line 7) and the claim of being ungrateful (line 8) into an obligation to feel immense gratitude all the time (line 13). By expressing an unreasonable expectation and taking the description to its extreme (immense gratitude, all the time; see Pomerantz, 1986), the formulation is designed to be disagreed with. In line 15, the client produces the disagreeing turn. However, through the laugh particles inserted in her disagreement, and by invoking the "reason versus feeling" distinction in her response, she also distances herself from the disagreement she expresses.

Extract 7 is another example of an exaggerating formulation. Earlier in the session, the therapist pointed out to the client that when other people treated her badly, she tended to blame herself. In responding to the therapist's arguments, the client took a somewhat critical stance toward her mother by admitting that her mother had a tendency to see things negatively. From line 1, the therapist, through a question, pursues her view that the mother's criticism of the client arises from her mother's general tendency of negative thinking, and that it is not the client's fault that her mother also views her as a bad person. In her delayed and extended response (lines 7-19), the client treats such a suggestion as reasonable, but she points out that while her "reasonable" side tells her that she should be proud of herself, feeling is stronger than reason.

\section{Extract $7 \mathrm{CT}$}

01 T: no tarkottaaks se sillon et ${ }^{\circ}$ sä oot huono, ${ }^{\circ}$ well does it mean then that ${ }^{\circ}$ you are bad, ${ }^{\circ}$

$03 \mathrm{~T}$ : jos äidillä on taipumus nähdä kaikki asiat huo ${ }^{\circ}$ nona, ${ }^{\circ}$ if your mother has a tendency to see everything as ${ }^{\circ} \mathrm{bad}^{\circ}$,

$04 \quad(1.3)$

05 T: ${ }^{\circ}$ negatiivisesti,

${ }^{\circ}$ as negative, ${ }^{\circ}$

$06 \quad(13.0)$

07 C: ei se välttämättä sitä tarkota et mä olen huono it doesn't necessarily meant that I'm bad 


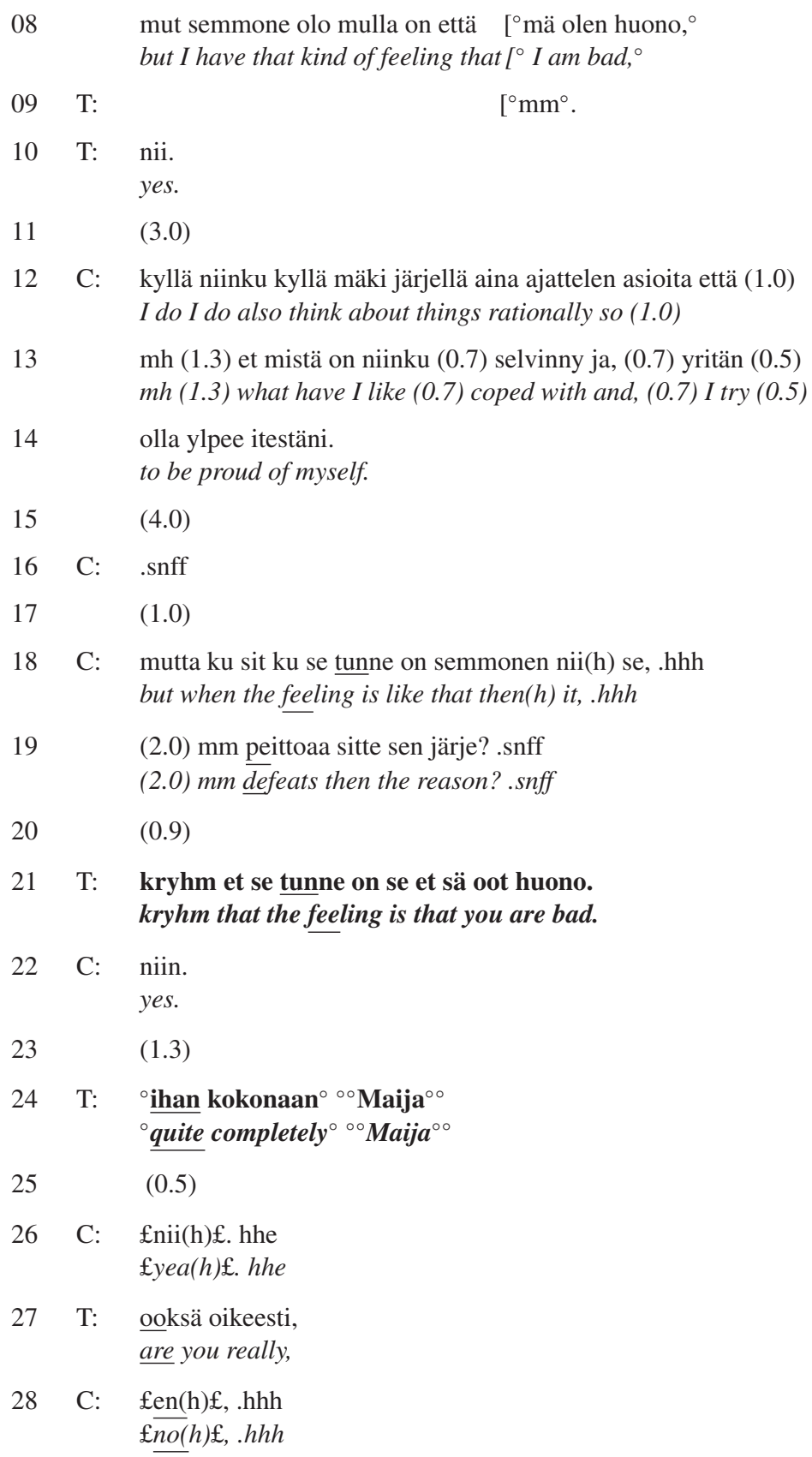

Lines 21-27 involve a stepwise shift from an initial formulation inviting agreement to one that clearly invites disagreement, thereby challenging the client's description of her emotional experience. The initial formulation recycles descriptive elements from the client's turns in lines 
18 (the feeling is) and 8 (I am /you are/ bad). Taken out of its broader context, this formulation could work like a highlighting formulation (see Extracts 1 and 2), the main work of which is to demonstrate that the therapist understands the client's emotions. However, as the sequence unfolds, the formulation becomes part of a project for challenging the client's beliefs. The client confirms the initial formulation in line 22 (in producing the response immediately, she seems to orient to the formulation as one indeed inviting confirmation). However, in line 24, after the confirmation, the therapist invites the client to reconsider her response by adding a new element to the formulation. The new element quite completely takes the description to its extreme. By asking the client to reconsider, the therapist seems to shift the direction of the projected answer: Now she is audibly inviting an answer in the negative. At the end of the turn the therapist whispers the client's name, thereby further increasing the pressure on the client to reject the formulation. The client hesitates to answer in line 25 but confirms the renewed formulation in line 26 . The confirmation is produced with laughter particles, which probably convey that the client recognizes that her answer is somehow problematic and not what the therapist is pursuing (see Potter \& Hepburn, 2010). In line 27 the therapist continues the challenging action through a question, and in line 28 , the client produces the kind of disagreement that the therapist had been audibly pursuing.

To conclude, exaggerating formulations transform the content of the description so as to engender the expectation to disagree with the formulation. In cases where the client agrees with such formulations, the therapist regularly pursues disagreement through subsequent increments until he/she receives the desired response.

\section{Summary of the Four Types of Formulation}

In this section, we have presented the classification of four types of formulation positioned visa-vis the client's description of his/her experience. All of these formulation types accomplished specific tasks in psychotherapeutic interaction. Table 1 summarizes these tasks and describes their main design and sequential features.

TABLE 1

Summary of the Four Types of Formulation

\begin{tabular}{|c|c|c|c|}
\hline $\begin{array}{l}\text { Type of } \\
\text { Formulation }\end{array}$ & Task of the Formulation & Lexical Features & Sequential Features \\
\hline $\begin{array}{l}\text { Highlighting } \\
\text { formulations }\end{array}$ & $\begin{array}{l}\text { Receive client's telling, } \\
\text { recognize therapeutically } \\
\text { dense material }\end{array}$ & $\begin{array}{l}\text { Recycling the words } \\
\text { from client's turn }\end{array}$ & $\begin{array}{l}\text { Invites confirmation of the } \\
\text { formulation }\end{array}$ \\
\hline $\begin{array}{l}\text { Rephrasing } \\
\text { formulations }\end{array}$ & $\begin{array}{l}\text { Focus client's telling on } \\
\text { subjective experience, } \\
\text { invite self-reflection }\end{array}$ & $\begin{array}{l}\text { Renaming client's } \\
\text { subjective experiences }\end{array}$ & $\begin{array}{l}\text { Invites extended } \\
\text { agreement/disagreement }+ \\
\text { elaboration of the formulation }\end{array}$ \\
\hline $\begin{array}{l}\text { Relocating } \\
\text { formulations }\end{array}$ & $\begin{array}{l}\text { Prepare, deliver, rework } \\
\text { interpretation }\end{array}$ & $\begin{array}{l}\text { Connections, } \\
\text { explanations, } \\
\text { symbolic talk }\end{array}$ & $\begin{array}{l}\text { Invites extended } \\
\text { agreement/disagreement }+ \\
\text { elaboration of the formulation }\end{array}$ \\
\hline $\begin{array}{l}\text { Exaggerating } \\
\text { formulations }\end{array}$ & Prepare, deliver challenging & $\begin{array}{l}\text { Extreme case } \\
\text { formulations }\end{array}$ & $\begin{array}{l}\text { Engenders an expectation to } \\
\text { disagree with the formulation }\end{array}$ \\
\hline
\end{tabular}


The task of highlighting formulations was to receive the clients' descriptive accounts: They were used to recognize the therapeutically salient parts of the clients' turns and invite them to continue their narrations. These formulations largely mirrored the content and lexical choices of the clients' turns. Thus, these formulations were strongly contingent on the clients' prior turns and made relevant a confirming response. These formulations also did preparatory work toward the subsequent actions of the therapist, as the therapists often returned to the content of these formulations in later phases of the sessions. This kind of turn design has much in common with the description of formulations that Bercelli et al. (2008, p. 47) have presented.

The task of rephrasing formulations was not only to receive the clients' accounts; rather they also transformed them into descriptions that were more apt for therapeutic work. In these formulations the therapists did not use the same lexical items as the clients but instead renamed the clients' experiences. By focusing on the clients' subjective experiences, rephrasing formulations invited the clients to engage in psychological self-reflection. The clients responded with agreements (or disagreements) extended with personal descriptions. In their next turns, the therapists continued to work with the clients' experiences.

Relocating formulations were connected to the preparation for, delivery, or reworking of interpretative statements. These formulations invited the clients to agree (or disagree) with the formulation and its extended elaboration.

Exaggerating formulations were used to prepare for or deliver a challenge to the client's way of thinking. Sequentially, the therapist redesigned a description given by the client in such a way that engendered an expectation to disagree with the formulation.

The analysis so far has considered formulations without reference to their distribution. Next we will move on to show the frequency of each type of formulation in our data and discuss their therapeutic functions.

\section{DISTRIBUTION AND TASK OF THE FORMULATIONS IN DIFFERENT THERAPY APPROACHES}

In the quantitative section of our study, all formulations from a dataset of 53 therapy sessions were collected and their distribution across the four different types of formulation was examined. The results are presented in Table 2 .

TABLE 2

Distribution of Four Formulation Types

\begin{tabular}{|c|c|c|c|c|c|c|}
\hline \multirow{2}{*}{$\begin{array}{l}\text { Type of } \\
\text { Formulation }\end{array}$} & \multicolumn{2}{|c|}{ Psychoanalysis } & \multicolumn{2}{|c|}{$\begin{array}{c}\text { Cognitive } \\
\text { Psychotherapy }\end{array}$} & \multicolumn{2}{|c|}{ Total } \\
\hline & $\mathrm{N}$ & $\%$ & $\mathrm{~N}$ & $\%$ & $\mathrm{~N}$ & $\%$ \\
\hline Highlighting & 37 & 34 & 48 & 41 & 85 & 38 \\
\hline Rephrasing & 31 & 29 & 35 & 30 & 66 & 29 \\
\hline Relocating & 39 & 36 & 0 & 0 & 39 & 17 \\
\hline Exaggerating & 0 & 0 & 19 & 16 & 19 & 8 \\
\hline Other & 1 & 1 & 14 & 12 & 15 & 7 \\
\hline Total & 108 & 100 & 116 & 100 & 224 & 100 \\
\hline
\end{tabular}


From our data, we found 224 formulations, and they were rather evenly divided between the two types of psychotherapy: 116 came from cognitive psychotherapy and 108 from psychoanalysis. Two types of formulation were found in both forms of psychotherapy: highlighting formulations (48 in cognitive psychotherapy and 37 in psychoanalysis) and rephrasing formulations (35 in cognitive psychotherapy and 31 in psychoanalysis). The other two types of formulation were only found in one or other of the psychotherapy approaches. All the relocating formulations appeared in psychoanalysis (36\% of the formulations in psychoanalysis were of this type) while all the exaggerating formulations appeared in cognitive therapy (16\% of the formulations in cognitive psychotherapy).

Seven percent of the formulations in our data did not belong to any of the four main categories (group "Other" in Table 2). Most of these formulations were found in cognitive psychotherapy, and they mainly served to facilitate the agenda management of the sessions (see Antaki, 2008; Antaki et al., 2005). However, because our concern was the ways in which the therapist's formulation dealt with the client's description of his/her experience, these formulations were not examined in this study.

In examining our data we noted that there were formulations that were found in both therapy approaches. Showing understanding (through highlighting formulations) and guiding the client toward focusing more on his/her own experience (through rephrasing formulations) thus appears to be the aim of the therapist in our data, regardless of the therapy approach. As far as formulations are concerned, these two therapeutic tasks are candidates for "common factors": practices that are at the core of therapy, regardless of the particular approach.

However, we also found formulations that were restricted to only one therapy approach. These formulations appear to be tools for doing approach-specific therapeutic tasks. Table 3 demonstrates the association between the frequency of these "approach-specific" (relocating and exaggerating) formulation types and therapeutic orientation.

Relocating formulations bear a close affinity to what psychoanalytic clinical theory refers to as interpretation. According to Greenson's classical clinical textbook (Greenson, 1967, p. 28), in an interpretation, the therapist proposes the meaning, source, or cause for certain events, or relates different events to the same shared origin, in order to bring hidden psychic events into consciousness. Relocating formulations involve a radical departure from some of the key features of the description formulated by the client. In a relocating formulation, the therapist proposes that the client's description involved a hidden layer of meaning referring to a place or time other than that explicitly stated in the account. In our data a considerably high portion $(36 \%)$ of all formulations found in psychoanalytic therapy sessions were relocating (see Table 2), which

TABLE 3

Frequency of Relocating and Exaggerating Formulations

\begin{tabular}{lccc}
\hline $\begin{array}{l}\text { Type of } \\
\text { Formulation }\end{array}$ & Psychoanalysis & Cognitive Psychotherapy & Total \\
\hline Relocating & 39 & 0 & 39 \\
Exaggerating & 0 & 19 & 19 \\
Total & 39 & 19 & 58 \\
\hline
\end{tabular}

Note. Chi-square $=58(3) ; p<.001$. 
suggests that interpretation remains a central task in psychoanalysis, at least as far as our data are concerned.

Exaggerating formulations seem to be a vehicle for what cognitive psychotherapy theory refers to as challenging the client's dysfunctional thoughts, which is one of the core tasks in the traditional theory of cognitive psychotherapy (Beck at al., 1979). Once identified, different kinds of techniques are used to challenge those thoughts and explore alternatives (Wills \& Sanders, 1997, p. 94-95). In our cognitive psychotherapy data, $16 \%$ of all formulations were of an exaggerating type. Thus, in cognitive psychotherapy, "approach-specific" formulations account for a smaller portion of all formulations than in psychoanalysis (where $36 \%$ of all formulations were relocating type). This might mean that our cognitive psychotherapist operates on the basis of more generic psychotherapy techniques (represented by highlighting and rephrasing formulations), or alternatively, the specific cognitive psychotherapy task of challenging the client's dysfunctional thoughts is managed more through other interactional means, such as questions.

\section{CONCLUSIONS}

In conversation analytic psychotherapy research, Vehviläinen et al. (2008, p. 197) and Peräkylä (2012) have questioned the applicability of the research findings to all forms of psychotherapy, observing that in most cases the data for CA studies on psychotherapy come from a particular type of psychotherapy. It is often reasonable to assume that the findings apply to the particular therapeutic approach in question, but the universal applicability of the findings across different types of therapy has not been addressed. In this article, we reported a comparative study of the uses of formulations in two types of psychotherapy: psychoanalysis and cognitive psychotherapy. We discovered that there were some types of formulations that were common to the two approaches and some that were distinct to one or other of the therapies.

The fact that two types of formulation (highlighting and rephrasing) occur with comparable frequency in both approaches does not, as such, prove that they are generalizable to psychotherapy as a whole: There might be other forms of psychotherapy where such formulations are not used. However, it is reasonable to assume that as they are shared by two opposing approaches, they might be related to the common factors of psychotherapy (see, e.g., Wampold, 2001), in other words, to generic features of psychotherapeutic interaction that might be crucial in enhancing psychotherapeutic change. In this article we have suggested that highlighting formulations are used by therapists to show that they are listening to the client and recognize the client's experiences (see Voutilainen, Peräkylä, \& Ruusuvuori, 2010). Therefore, these formulations are a means of showing empathy, which is considered to be an important factor in all psychotherapeutic relationships and is a key building block to a good working alliance (Horvath, 2001; Wampold, 2001). We also suggested that rephrasing formulations serve as a means of focusing the client's talk on his/her subjective experience. A common factor may also be involved here: Directing the client's attention to emotional experiences is also shown to be a common factor of successful treatment (Lambert \& Barley, 2001). To put it in the terms of Fonagy et al. (2002), these formulations may be geared to enhance mentalization and self-reflection in the client.

In addition to the formulations found in both types of therapy, there were two types of formulation that were found in only one or other approach. These "approach-specific" formulations served to facilitate a key aim of the respective therapeutic approach. While the interpretative 
task of formulations in psychoanalysis has been discussed in earlier research (see Antaki, 2008; Peräkylä, 2004; Vehviläinen, 2003), we are first to address the role of exaggerating formulations in challenging the client's dysfunctional thoughts in cognitive psychotherapy. By showing the genuinely different formulation practices in the two types of psychotherapy, we also showed that, at least in our data, the interactional differences between these two therapeutic approaches are still real, even though the theoretical frameworks of these approaches have recently converged. Thus, this kind of CA approach can complement earlier comparative psychotherapy research by showing the ways in which specific interactional patterns are accomplished in different therapies, thereby revealing what might be approach specific (see Kondratyuk \& Peräkylä, 2011).

In this article we have presented a detailed qualitative analysis of the similarities and differences of formulating practices in cognitive psychotherapy and psychoanalysis. Although our data collection methods, as in other qualitative studies, did not meet all the criteria for quantitative analysis (e.g., random sampling of the data), we tested the association between therapeutic orientation and frequency of relocating and exaggerating formulations with the chi-square test, and quantification served as a means of making the similarities and differences between the two therapy approaches more visible (see Arminen, 2009, p. 49). Because the comparative analysis of the distribution of certain types of interactional patterns across different therapy approaches has a quantitative logic, it would be important to establish the generality of our findings with more data involving several practitioners.

According to Drew (2003, p. 306), formulations are associated with core tasks of participants in different institutional settings. He points out that though these tasks are not unique to particular institutional setting, they are relatively restricted. The formulations that we studied were related to the institutional tasks of psychotherapy in two ways. The two types of formulation that we found from both forms of psychotherapy were vehicles for generic psychotherapeutic tasks of conveying empathy and directing the client's attention to his/her subjective experience. The two other types of formulation were related to the core tasks of specific psychotherapeutic approaches.

Even though specific types of formulation can perform rather specific tasks (such as exaggerating formulations serving to challenge dysfunctional thoughts), it also appears that the same kind of formulations can be found in surprisingly different settings. The exaggerating formulations found in cognitive psychotherapy seem to have many similarities with the argumentative use of formulations in the radio call-in shows investigated by Hutchby (1996, see also Drew, 2003). This may mean that there can be similar interactional tasks in rather different institutional settings. In both cases, these formulations are tendentiously constructed to challenge the client's (or the caller's) previous talk and reveal its absurdity. In both cases, extreme case formulation is one design feature of this kind of formulations.

The parallel between the formulations in cognitive psychotherapy and radio call-in programs shows how tricky a task it is to determine whether research findings regarding specific interactional practices (such as formulations) in one setting also apply to some other settings. In line with Vehviläinen et al. (2008) and Peräkylä (2012), we began the current study with the assumption that research results based on data obtained from one specific psychotherapy approach cannot, without problems, be generalized to and be considered representative of psychotherapy as a whole, and our study demonstrated some of the limitations of generalizing findings about formulations across two different psychotherapy approaches. Nevertheless, it appears that we can find surprisingly similar practices in institutional settings, such as cognitive psychotherapy and radio call-in shows, that are, in a broader sociological sense, quite far apart. This leads us to 
some theoretical questions regarding institutionalization. In an interactional sense, institutions are composed of different practices. The "official" boundaries between institutions, i.e., boundaries between different psychotherapy approaches, or the boundaries between psychotherapy and other institutions such as medical consultation, or, for that matter, a radio call-in program, are not necessarily boundaries that separate practices. Although practices such as different ways of formulating cross these boundaries, perhaps they do not even need to do so. However, in order to answer these intriguing questions, more comparative interactional research is needed.

\section{REFERENCES}

Antaki, C. (2008). Formulations in psychotherapy. In A. Peräkylä, C. Antaki, S. Vehviläinen, \& I. Leudar (Eds.), Conversation analysis and psychotherapy (pp. 26-42). Cambridge, England: Cambridge University Press.

Antaki, C., Barnes, R., \& Leudar, I. (2005). Diagnostic formulations in psychotherapy. Discourse Studies, 7, 627-647.

Arminen, I. (2009). On comparative methodology in studies of social interaction. In M. Haakana, M. Laakso, \& J. Lindström (Eds.), Talk in interaction: Comparative dimensions (pp. 48-69). Helsinki, Finland: Finnish Literature Society.

Beck, A., Rush, J., Shaw, B., \& Emery, G. (1979). Cognitive therapy of depression. New York, NY: Guilford.

Bercelli, F., Rossano, F., \& Viaro, M. (2008). Clients' responses to therapists' re-interpretations. In A. Peräkylä, C. Antaki, S. Vehviläinen, \& I. Leudar (Eds.), Conversation analysis and psychotherapy (pp. 43-62). Cambridge, England: Cambridge University Press.

Clift, R. (2001). Meaning in interaction: The case of "actually." Language, 77, 245-291.

Davis, K. (1986). The process of problem (re)formulation in psychotherapy. Sociology of Health \& Illness, 8, 44-74.

Drew, P. (2003). Comparative analysis of talk-in-interaction in different institutional settings: A sketch. In P. J. Glenn, C. D. LeBaron, \& J. Mandelbaum (Eds.), Studies in language and social interaction: In honor of Robert Hopper (pp. 293-308). Mahwah, NJ: Erlbaum.

Elliot, R., Stiles, W., Marer, A., Hill, C. E., Friedlander, M. L., \& Margison, F. R. (1987). Primary therapist response modes: Comparison of six rating systems. Journal of Consulting and Clinical Psychology, 55, 218-223.

Fonagy, P., Gergely, G., Jurist, E. L., \& Target, M. (2002). Affect regulation, metallization and the development of the self. New York, NY: Other Press.

Greenberg, L. (1997). Working with emotions in psychotherapy. New York, NY: Guilford.

Greenson, R. (1967). The technique and practice of psychoanalysis. London, England: Hogarth.

Guidano, V. (1991). The self in progress: Towards a post-rationalistic cognitive therapy. New York, NY: Guilford.

Haakana, M., Laakso, M., \& Lindström, J. (2009). Introduction: Comparative dimensions of talk in interaction. In M. Haakana, M. Laakso, \& J. Lindström (Eds.), Talk in interaction: Comparative dimensions (pp. 15-47). Helsinki, Finland: Finnish Literature Society.

Hak, T., \& De Boer, F. (1996). Formulations in first encounters. Journal of Pragmatic, 25, 83-99.

Heritage, J., \& Watson, R. (1979). Formulations as conversational objects. In G. Psathas (Ed.), Everyday language: Studies in ethnomethodology (pp. 123-162). New York, NY: Irvington.

Horvath, A. O. (2001). The alliance. Psychotherapy, 4, 365-372.

Hutchby, I. (1996). Power in discourse: The case of arguments on a British talk radio show. Discourse \& Society, 4 , $481-497$.

Hutchby, I. (2005). Active listening: Formulations and the elicitation of feeling-talk in child counseling. Research on Language and Social Interaction, 3, 303-329.

Kondratyuk, N., \& Peräkylä, A. (2011). Therapeutic work with the present moment: A conversation analytical study of guidance into immediacy. Psychotherapy Research, 3, 316-330.

Lambert, M. J., \& Barley, D. E. (2001). Research summary on the therapeutic relationship and psychotherapy outcome. Psychotherapy, 4, 357-361.

Peräkylä, A. (2004). Making links in psychoanalytic interpretations: A conversation analytic view. Psychotherapy Research, 14, 289-307.

Peräkylä, A. (2005). Patients' responses to interpretations: A dialogue between conversation analysis and psychoanalytic theory. Communication \& Medicine, 2, 163-176. 
Peräkylä, A. (2011a). After interpretation: Third position utterances in psychoanalysis. Research on Language and Social Interaction, 3, 288-316.

Peräkylä, A. (2011b). Validity in research on naturally occurring social interaction. In D. Silverman (Ed.), Qualitative research (3rd ed., pp. 365-382). London, England: Sage.

Peräkylä, A. (2012). Conversation analysis in psychotherapy. In T. Stivers \& J. Sidnell (Eds.), Handbook of conversation analysis (pp. 551-574). Chichester, England: Blackwell.

Peräkylä, A., Antaki, C., Vehviläinen, S., \& Leudar, I. (2008). Conversation analysis and psychotherapy. Cambridge, England: Cambridge University Press.

Peräkylä, A., Ruusuvuori, J., \& Vehviläinen, S. (2005). Introduction: Professional theories and institutional interaction. Communication \& Medicine, 2, 105-109.

Peräkylä, A., \& Vehviläinen, S. (2003). Conversation analysis and the professional stocks of interactional knowledge. Discourse \& Society, 6, 727-750.

Pomeranz, A. (1986). Extreme case formulations: A way of legitimizing claims. Human Studies, 9, 219-229.

Potter, J., \& Hepburn, A. (2010). Putting aspiration into words: "Laugh particles," managing descriptive trouble and modulating action. Journal of Pragmatics, 42, 1543-1555.

Sacks, H., Schegloff, E. A., \& Jefferson, G. (1974). A simplest systematics for the organization of turn-taking for conversation. Language, 50, 696-735.

Safran, J. (1998). Widening the scope of cognitive therapy: The therapeutic emotion and the process of change. London, England: Jason Aronson.

Sandler, J. (1994). The past unconscious and the present unconscious: A contribution to a technical frame of reference. The Psychoanalytic Study of the Child, 49, 278-292.

Schegloff, E. A. (1993). Reflections on quantification in the study of conversation. Research on Language and Social Interaction, 26, 99-128.

Sorjonen, M.-L. (2001). Responding in conversation: A study of response particles in Finnish. Amsterdam, The Netherlands: John Benjamins.

Stiles, W., Shapiro, D., \& Firth-Conzens, J. (1988). Verbal response mode use in contrasting psychotherapies: A withinsubjects comparison. Journal of Consulting and Clinical Psychology, 56, 727-733.

Vehviläinen, S. (2003). Preparing and delivering interpretations in psychoanalytic interaction. Text, 23, 573-606.

Vehviläinen, S., Peräkylä, A., Antaki, C., \& Leudar, I. (2008). A review of conversation practices in psychotherapy. In A. Peräkylä, C. Antaki, S. Vehviläinen, \& I. Leudar (Eds.), Conversation analysis and psychotherapy (pp. 188-197). Cambridge, England: Cambridge University Press.

Voutilainen, L., Peräkylä, A., \& Ruusuvuori, J. (2010). Recognition and interpretation: Responding to emotional experience in psychotherapy. Research on Language and Social Interaction, 43, 85-107.

Wampold, B. E. (2001). The great psychotherapy debate: Models, methods, and findings. Mahwah, NJ: Lawrence Erlbaum.

Watzke, B., Rueddel, H., Koch, U., Rudolph, M., \& Schultz, H. (2008). Comparison of therapeutic action, style and content in cognitive-behavioral and psychodynamic group therapy under clinically representative conditions. Clinical Psychology and Psychotherapy, 15, 404-417.

Wills, F., \& Sanders, D. (1997). Cognitive therapy: Transforming the image. London, England: Sage. 